\title{
AUTHENTICITY LOST? THE SIGNIFICANCE OF CULTURAL VILLAGES IN THE CONSERVATION OF HERITAGE IN SOUTH AFRICA
}

Chris Boonzaaier

chris.boonzaaier@up.ac.za

Department of Anthropology \& Archaeology University of Pretoria

Pretoria, South Africa

Tel: +27 124202597

\author{
Harry Wels \\ h.wels@vu.nl \\ Dept. Organisation Sciences \\ Vrije Universiteit Amsterdam \\ The Netherlands \\ African Studies Centre Leiden; \\ University of the Western Cape, South \\ Africa
}

\begin{abstract}
Based on a(n) (interrupted) period of 15 years of fieldwork, this study explores the question whether cultural villages in South Africa are to be considered an effective way to conserve a particular cultural heritage in an authentic way. In order to answer this question, three notions of authenticity are juxtaposed with three types of cultural villages. The outcomes reveal a nuanced answer that suggests that some types of cultural villages do contribute to the conservation of an authentic cultural heritage, but not all. The research also shows how cultural heritage tourism is often haunted and influenced by old colonial stereotypes and exoticism.
\end{abstract}

Keywords: cultural villages, cultural heritage, authenticity, commoditisation, exoticism.

\section{Introduction}

In a time and age of mass tourism (Sezgin and Yolal 2012) people travel across the globe in search of novel experiences, cultural authenticity and out of curiosity (MacCannell 1973; Urry 1990; Scheyvens 2002). Tourism has always made use of suggesting exoticism-sold-as-authenticity to market its destinations, especially Western tourism relying heavily on images of cultural 'Others' from a colonial past. A colonial heritage prevails that generally distorts and reduces the Western view of cultural 'Others' to a stereotype of how 'Africans' are, or 'people from the Orient', or any other people or place outside of Western 'civilisation' (Said 1978; Wels 2004). In the post-colonial era the concept of authenticity became a projection of tourists' own beliefs, expectations, preferences, stereotypical images and consciousness onto toured objects and toured 'Others' (Scheyvens 2002; Wels 2004; Boonzaaier \& Grobler 2012; Ndlovu 2013).

Under the influence of this globalised label of authenticity to be found in remote places, cultural villages were established as representative of an imagined authentic past, usually characterised by either nostalgia or romanticism. As an alternative form of tourism cultural villages would provide another motivation for people to travel, explore, rediscover and fulfil a primordial self and to keep a 
distance from or transcend daily modern lives (Wang 1999; Scheyvens 2002; Wels 2004).

A considerable number of studies on the authenticity of cultural villages have been done in South Africa ${ }^{1}$. The general conclusion is that many of these villages have been constructed for commercial purposes by satisfying tourists' search for authenticity in the sense of a 'real African experience' (Van Veuren 2004; Marschall 2007; Ndlovu 2013). The commercialisation and commoditisation of culture leads, in the context of cultural villages, to 'staged authenticity'. This means that the cultural product is presented and even accepted by tourists as authentic although it has lost its cultural meaning and has become obsolete (MacCannell 1973). Cohen (1988:373) remarks that '...commoditisation....allegedly destroys not only the meaning of cultural products for the locals but, paradoxically, also for the tourists. It thus emerges that, the more tourism flourishes, the more it allegedly becomes a colossal deception'.

But is this fatalistic perspective all there is, especially in the context of the question if cultural villages, through tourism, can at the same time contribute to the conservation of heritage? Have all types of cultural villages (see below) fallen prone to commercialisation and commoditisation? Or can we distil hope from certain types of cultural villages for the conservation of heritage? Or to make it even more specific, is there still hope for some sort of authenticity in the conservation of heritage of cultural villages? In this article we try to assess these questions in the context of South Africa. The article is structured as follows: We first conceptually ground the article in an elaboration of the various 'shades' of authenticity in the portrayal of culture, followed by an explanation of the notion of cultural villages, resulting in a typology of three. With this in mind we can turn our attention to the methods that we have used for this longitudinal research of 15 years, before we present the three case studies linked to and embedded in the typology and the various nuances that we argue for with regard to the concept of authenticity. The article is concluded with an attempt to answer the questions that we posed in this introduction

\section{The issue of authenticity in the portrayal of culture}

The terms 'authentic' and 'tradition(al)' feature in almost all internet advertisements on cultural villages viewed. However, in some cases where the term authentic is not included, it appears that the term tradition implies the notion of authenticity. For example, the Basotho Cultural Village in the Free State is advertised as 'a unique South African cultural village where visitors are invited to

\footnotetext{
${ }^{1}$ As we do not argue for a comparison of cultural villages across other parts of the world, we stay close to literature on the phenomenan of cultural villages in South Africa and to our case studies.
} 
experience authentic hospitality and learn about traditional arts, crafts and ways of life of the Basotho people'. ${ }^{2}$

What is considered authentic or tradition is often articulated within the idiom of nostalgia which relies heavily on images from a colonial past that depict and encourage stereotypical cultural images (Palmer 1994; Echtner \& Prasad 2003; Boonzaaier \& Grobler 2012). However, from a scientific viewpoint, there is no such thing as a totally uncontaminated traditional culture which is absolute and original on which (authentic) tradition would rely (Wang 1999). Culture is always in process whether because of innovations by the bearers thereof or because of outside influences. Since time immemorial people have been adopting and assimilating elements of cultures, hence giving rise to the notion of hybridity (Bhabha 1994; Acheraïou 2011).

As mentioned above, the concept of authenticity has been used to suggest that people in modern societies travel in search of cultural authenticity which would be found outside the own cultural context among the so-called primitive 'Other' which as yet have not been contaminated by modernity. Hence, authenticity refers to the original, the pure and innocent. On the other hand, it is argued that what is regarded as authentic is a social construct and that nobody is able to indicate the original. As a social construct the concept of authenticity is based on stereotyped images created by the mass media in all its diverse forms (Palmer 1994:806; cf. Echtner \& Prasad 2003:669; Boonzaaier \& Grobler 2012:61). This is especially true in the case of travellers that do not necessarily have expert knowledge in respect of ethnic objects and practices and are largely exposed to and dependent on promotional material. Hence, there will be a difference in criteria of authenticity between ordinary travellers and those with expert knowledge, such as curators, historians, ethnographers and anthropologists.

Hence, it follows that 'intellectuals and more alienated individuals will engage in a more serious quest of authenticity than most rank-and-file members of society' (Cohen 1988:376). In this regard Waitt (2000:847) alleges that 'authenticity can be defined in the tourist's own terms'. This leads one to ask to what extent is the average tourist (the non-expert) really in quest of the original, the real, the authentic? To what extent is the average tourist satisfied with the fake or staged authenticity? These questions relate to postmodern approaches according to which the contrived, the copy, and imitation are justified and where reality depends on how well the staged authenticity is experienced and accepted (Wang 1999:355).

From the academic literature it is clear that one can hardly talk about issues such as identity construction and representation, heritage and heritage conservation without any attention being given to discourses on authenticity. Within the context of the significance of cultural villages in heritage conservation, the core question

\footnotetext{
${ }^{2}$ hhtp://www.southafrica.net/za/en/articles/entry/article southafrica.net basotho cultural village, accessed 31/03/2014, our emphasis
} 
that should be asked according to Ndlovu (2013:54), is whether 'the cultural villages represent 'myth or reality' (cf. Tomaselli \& Wang 2001).

In order to address the shortcomings with regard to the concept of authenticity, particularly the realisation that 'many tourist motivations or experiences cannot be explained in terms of the conventional concept of authenticity', Wang considered the concept in terms of an 'existential' philosophical usage of the notion (1999:35).

According to Wang (1999:351), objective authenticity refers to 'the authenticity of the original', the true, the real, museum kind originality of arts and practices - 'the toured objects to be perceived by tourists'. As indicated above, what is judged as authentic or inauthentic or even staged authenticity is determined by experts or intellectuals who decide what would appeal to tourists in search for an epistemological experience of toured objects and practices. The difficulty with this use of the concept of authenticity in tourism is that it becomes knowledge based which does not allow for any authentic experience by tourists or laypersons without the necessary knowledge base. In the process the touristic search for authenticity, according to MacCannell (1973), becomes no more than an epistemological experience of toured objects which are found to be authentic (Wang 1999: 353). What is more is that what is regarded as inauthentic or staged authenticity by experts may be regarded as authentic from an indigenous local perspective. People adapt to changing natural and social environments by also adopting new cultural objects and practices. Experts and even the modern tourist might not necessarily be aware of these changes or apply criteria which search 'for the pristine, the primitive, the natural, that which is as yet untouched by modernity' (Cohen 1988: 374).

On the contrary, constructive authenticity refers to a construct of the mind authenticity that is projected onto objects by tourists. 'Things appear authentic not because they are inherently authentic but because they are constructed as such in terms of points of view, beliefs, perspectives, or powers' (Wang 1999: 351). This projected authenticity is socially constructed and hence negotiable in terms of points of view, beliefs, and perspectives. As indicated above, the role of the media in the creation of perspectives and images of 'Others' should never be underestimated in the building of (stereotyped) images, dreams and expectations (cf. Wels 2004). It can have a manipulating effect on the way that local culture is presented by cultural villages. The projection of tourists' beliefs, stereotyped images and expectations onto toured objects, implies that they are perceived as 'signs or symbols of authenticity' and as such they are experienced as authentic. Within this context, what tourists search for 'is not the original (objective authenticity) but symbolic authenticity which is the result of social construction' (Wang 1999:354). Hence, it is particularly within the context of constructive authenticity that the process of globalisation reveals itself distinctively.

The existential notion refers to the true self. In modern Western society man has lost his true self and hence a quest for the meaning of Being, the authentic Self, is 
activated. This approach differs from the objective and constructive approaches as it is not object but subject related. In search of this existential authentic state of Being, the 'ways of life (cultures) in which people are supposed as freer, more innocent, more spontaneous, purer and truer to themselves, are idealised and endowed with romanticism and nostalgia' (Wang 1999: 357) (my insertion). Hence, in order to discover the true Self the outsider or tourist participates in the activities of the 'Other' and by doing so, the authentic Self is revived. It is the authentic experience, as perceived by the tourist, rather than the authenticity of toured objects that is important. Within this context toured objects are rather regarded as a means to discover oneself. It is argued that cultural villages fit the role of toured objects as they reflect the supposed lives of people in their innocent, pure and true state, and as such serve as a medium for discovering oneself (Wang 1999; Lengkeek 2008; Monare, Moswete, Perkins \& Saarinen 2016:166-167).

Wang's (1999:352-361) distinction between different notions of authenticity provides a means to contribute to our understanding of the significance of cultural villages in the conservation of heritage. This implies that cultural villages be assessed in terms of the notions of objective, constructive or symbolic and existential authenticity. Next we will introduce the notion of the cultural village and, following Van Veuren (2004:141), distinguish between three types of cultural villages and juxtapose them in the analysis (see the section below on Methods) with these three notions of authenticity.

\section{The notion of cultural villages}

According to Saarinen (2007:139) cultural villages can be seen as specific forms of cultural tourism in rural contexts. Cultural villages are usually reconstructed traditional homesteads with the specific purpose to attract, entertain and satisfy the expectations and needs of tourists on the one hand and the expectations (particularly financial benefits) of investors/ shareholders/stakeholders on the other hand (Monare et al. 2016:171) . $^{3}$

To attract tourists, cultural villages attempt to compromise between non-local demand and what local cultures have to offer. Hence, particular aspects of indigenous culture are adapted, packaged and dramatised to serve the expectations and tastes of tourists and by so doing, create financial profits which largely go into the pockets of the stakeholders (Van Veuren 2004). In this attempt to compromise Saarinen (2007:141) remarks that 'cultural representations and knowledge utilised may potentially imitate more non-local needs and images than the cultural identities of the people depicted'. In the process local culture is commoditised as particular cultural objects, traditional practices and activities and

\footnotetext{
${ }^{3}$ And should for that reason not be confused with other forms of tourism in South Africa like 'township tourism' (Booyens 2010), which is about a form of tourism to places that were never specifically created or meant for tourism purposes.
} 
the complex symbolic meanings which support them, 'are imaged and transformed into saleable products' (Cohen 1988: 373) - hence, replacing their authentic meaning with a commercial value (cf. Robinson 1999:11). Cultural villages have been accused of being guilty of this practice as cultural practices such as religious rituals, rites and festivals are attenuated and adapted to conform to tourist expectations. In this respect Wels (2004:90) comments that visitors often 'want to see Africans and the African landscape in the way they are taught to see them in their formative years of image moulding'. This process of image moulding tends to romanticise Africa and its peoples. However, eventually the ritual becomes a staged performance in exchange for money (Cohen 1988; Greenwood 1989).

Cohen (1988: 382) states that although a cultural product can be changed through commoditisation, it can acquire a new meaning for its creators. 'Thus, what used to be a religiously meaningful ritual for an internal public, may become a culturally significant self-representation before an external public' (Cohen (1988: 382). Hence, the commoditised product(s) is (are) used to establish a reconstructed cultural identity. Important to note in the African context, is that the two meanings are not necessarily mutually exclusive but could be supplementary in the sense that new meanings may supplement old ones. To the outsider it may appear that commoditisation causes a total transformation of meaning. However, Cohen (1988:382) states that 'the performers themselves do not necessarily perceive that such a transformation had in fact occurred. Rather...they may perceive an often astonishing degree of continuity between the old and the new situation' (cf. MacCannell 1973, Marschall 2007).

Cultural villages have also been characterised as essentialistic in the sense that they present the indigenous cultures as static and unchanged which would be responsible for a 'museumification' of identity (Ndlovu 2013). In particular this is also true for South Africa. With a few exceptions, such as Bakoni Malapa Open Air Museum in Limpopo Province (http://www.southafrica.net/za/en/articles/entry/ article-southafrica.net-bakone-malapa-open-air-museum, accessed on 31/03/2014) and the Basotho Cultural Village in the Free State (http://www.southafrica.net/za/ en/articles/entry/article-southafrica.net-basotho-cultural-village, accessed on 31/03/2014), no attempt has been made to depict not only the original, 'authentic' states, but also the changes that have taken place over time. Hence, cultural villages in South Africa have been criticised for presenting cultural practices in a romantic, superficial, a-historical and static way (De la Harpe et al. 1999; Lengkeek 2008). Clearly there is less interest in a historical depiction of changes that have taken place over time. The 'original, authentic state' is based on interpretations and reinterpretations of remnants of the past obtained from mostly old archaeological and anthropological records supplemented by the memories of old people as experienced by them or conveyed to them by their forefathers (Lengkeek 2008; Van Vuuren 1983).

Other criticisms of the representations of cultural identities in South Africa and Africa in general is that they represent myths instead of culture (Tomaselli \& Wang 
2001), and that they reproduce stereotypes, generated by the West's desire for exoticism and imaginations of the so-called primitive 'Other' (Scheyvens 2002; Wels 2004). Boonzaaier and Grobler (2012:61) remarks that '(o)nce a particular stereotypical image of a place has been ...constructed..., people tend to accept and internalise that image, even in the absence of any supporting evidence. Such naivety makes stereotypes tenacious and resistant to change. The success of the tourism industry relies heavily on the (stereotypical) images used to represent Third World destinations. Stereotyped representations of culture are regularly criticised as 'always limiting' and 'fixated' as they do not represent the whole cultural picture and do not recognise changes. In fact, cultural villages have a tendency to select those cultural elements/commodities that will satisfy expectations of tourists (cf. Scheyvens 2002:38). In the process local culture is distorted since cultural villages do not necessarily reflect 'traditional' or 'authentic' cultural practices. Under these circumstances it is impossible to obtain a holistic view or profound understanding of local culture. Whatever is at display or represented is extremely superficial in character. Hence, visitors leave the cultural village with a skewed image and understanding of local culture (Bhabha 1983).

\section{Types of cultural villages}

Van Veuren (2004:141) categorises South African villages into three types based on their ownership and funding structure:

Privately owned villages are mainly owned by non-local white entrepreneurs 'whose members range from small businesses held by individuals and families to large corporations' (Ndlovu 2013:54). Hence, they are outsiders to the culture depicted at the village and the local communities. The purpose of these cultural villages is simply to make profit out of non-local customers. This is achieved by satisfying the stereotyped images and expectations of the tourists by means of packaging real and/or imagined representations of the cultural features of a destination. No particular attention is given to the way in which the people themselves want to be represented (Van Veuren 2003:70; cf. Saarinen 2007: 145; 2009:65; Boonzaaier \& Grobler 2012:61; Ndlovu 2013:54).

The second type of private sector-owned cultural villages comprises of indigenous entrepreneurs. Although their primary aim is also to make a profit, they usually also demonstrate a strong commitment to cultural conservation and education, as well as job creation in the related communities. The indigenous private owners are mainly insiders to the culture demonstrated in a cultural village (Van Veuren 2003:140; cf. Saarinen 2007:145; Ndlovu 2013: 55).

The third type of cultural villages is established by various bodies of the public sector. The primary aim is to preserve elements of indigenous cultural practices. Although the intention is that these villages should be sustained by tourism, they still remain heavily dependent on government subsidies. Hence, the state can 
manipulate these villages to comply with larger socio-political imperatives and policy frameworks. This dependence together with associated bureaucratic practices in respect to tourism demand issues and local communities may endanger their sustainability seriously (Van Veuren 2004: 145; cf. Marschall 2007; Ndlovu 2013; Saarinen 2007:145).

\section{Research method}

For the purposes of this study, three cultural villages were selected, firstly on account of their representation of the three types of villages distinguished by Van Veuren (2004) - Lesedi Cultural Village in the Northwest Province and two from the Limpopo Province of South Africa, namely Thomo Living Cultural Heritage Museum and Tsonga Kraal Open-Air Museum, secondly because of the lead author's familiarity with and access, crucial for this kind of anthropological research (Hammersley \& Atkinson 1983; van der Waal 2009), to the villages and the actors who were from the adjacent rural settlements.

The research was conducted over an interrupted period of 15 years during which three cultural villages, selected on account of the specific types of villages they present (see further down), were periodically visited. During these visits a basic qualitative research strategy was followed according to which the technique of observational interrogation (Coertze 1993) was in order to determine the meaning of certain objects and cultural practices. This implied that the manager (in the case of Lesedi Cultural Village), the owner (in the case of Thomo Living Cultural Heritage Museum) and the curator (in the case of Tsonga Kraal Open-Air Museum/ Muti wa Tsonga Open-Air Museum) were interviewed about the main purpose of the village, the contents of the respective programmes, the importance of authenticity in the lay-out of the villages and the presentation of the respective programmes. In addition the actors were interviewed, individually (Spradley 1979) and by means of focus group discussions (cf. Kamberelis and Dimitriades 2013) ${ }^{4}$ to determine how they perceived the 'traditional/authentic' meaning of objects and practices ${ }^{5}$. The reason for this approach was motivated by the remarks of Cohen (1988: abstract) that concepts of authenticity could change over time: 'Authenticity is conceived as a negotiable rather than primitive concept, the rigor of its definition by subjects depending on the mode of their aspired touristic experience. New cultural

\footnotetext{
${ }^{4}$ On average seven actors per village, which included women, usually took part in focus group discussions. On average these discussions lasted for about 90 minutes.

${ }^{5}$ Although the research was conducted over a period of 15 years, not all villages were established at the same time. Hence, some village were visited more than others. Lesedi was visited only twice, while Thomo village was visited at least six times. Tsonga kraal, which was established in the mid 1970s, and which was part of the ongoing research of one of the authors, was visited more than thirty times.
} 
developments may also acquire the patina of authenticity over time - a process designated as "emergent authenticity".

During the course of the visits to the cultural villages it occasionally happened that the researcher was invited to participate in the activities, such as dancing, pottery and indigenous cuisine in accordance with indigenous etiquette. This participation which, according to the literature, can be described as participant observation (Adler \& Adler 1994; Schurink 1998; Strydom \& Delport 2005), provided a further opportunity to interview staff on what had been observed and also to develop a sense of what was being experienced by tourists when they participated in socalled 'authentic' cultural practices.

In the last instance the data collected was analysed and compared with relevant ethnographic material and documents. Hence, the lay-out of the cultural villages, the history of the people linked to the cultural village, the various cultural activities performed, were all compared with the relevant documentation on the basis of their meaning, the purpose being to determine the extent to which 'authentic' cultural heritage has been conserved.

\section{Case studies}

\section{Lesedi Cultural Village}

\section{Characteristics}

Lesedi Cultural Village belongs to the first type of cultural villages and is located to the west of Pretoria in the Northwest Province of South Africa. The village was established in 1993 and formed part of a private multinational hotel chain, the Protea Hospitality Corporation, which is the largest hotel management group in South Africa (Saarinen 2007:146). In 1998, Tourvest Holdings, a JSE listed tourism company, acquired a controlling interest in Lesedi. Under the direction of Kingsley Holgate, a National Geographic Explorer, and Alan Louw, Lesedi was re-launced in 1999. Alan serves as managing director. Both Kingsley and Alan are shareholders in Lesedi. In 2008 the controlling interest in Tourvest Holdings was acquired by Guma Tourism Holdings, a Black owned tourism company. Hence Lesedi has acquired high BEE status. Lesedi offers conference facilities and 38 'themed guest rooms to accommodate guests in first class comfort' (http://www.lesedi.com/cultural.htm, accessed on 31/03/2014).

Yet, despite these modern day amenities and comforts, Lesedi's vision is 'to provide an authentic showcase of the traditional cultures of some of the well-known African tribes' (http://www.lesedi.com/cultural.htm, accessed on 31/03/2014) (my emphasis). For this purpose five 'traditional homesteads' representative of five different cultural groups (Zulu, Xhosa, Basotho, Ndebele and Pedi) have been 
established. Local families live in each of these five homesteads and visitors are encouraged to observe and experience the African culture by either enjoying a short tour of the five homesteads/villages or 'actually living among these families in guest accommodation, offering all the necessary modern day amenities and comforts discerning visitors are accustomed to' (http://www.lesedi.com/ cultural.htm, accessed on 31/03/2014) (cf. Saarinen 2007: 147; Van Veuren 2004: 151).

After arrival and a 'vibrant traditional African welcome and a refreshing welcome drink' during which the 'Lesedi Marimba Band players from West Africa' make music for the visitors, visitors first get the opportunity to visit the Ndebele craft market where Ndebele mural art can be appreciated and arts and crafts (particularly beadwork) can be purchased as souvenirs. This is followed by a multivisual presentation of the peopling of southern Africa, followed by guided tours through different ethnic 'traditional homesteads', storytelling and restaurant services. After a few drinks in the bar, visitors meet in the 'Traditional Dance Boma' where song and dance, not representative of any particular group in particular, are performed. The dances range from 'traditional' ethnically based dances to dances (so-called gumboot dancing) which evolved on the mines during the $20^{\text {th }}$ century. The dancers are all dressed up in traditional attire (leopard skins, feathers and spears while the attire of those performing the gumboot dancing wear helmets, rubber boots and other mining gear. The performances culminate in communal dancing and singing with the guests around the fire.

The entire tour is usually concluded with dinner in the Nyama Choma restaurant with 'delicacies from North, East and South Africa'. Again the Lesedi Marimba Band which is even composed by musicians such as guitar players, make music.

\section{Evaluation}

Lesedi Cultural Village is a multicultural village which represents constructed authenticity. As a privately owned company composed of various outside shareholders the main aim is to make a profit. The fact that it has obtained BEE status, makes no difference in terms of its main aim. Although Guma Tourism Holdings is a Black owned tourism company it is an outsider in the original meaning of the word. In order to make a profit the strategy is to entertain and to satisfy the Western images and expectations of Africa and Africans (cf. Wels 2004) which are the construct of the human mind based on stereotypical images created over time by the international media (cf. Boonzaaier \& Grobler 2012).

However, the different homesteads have been established totally out of context in the architectural styles of idealised traditional homesteads of the past. It is not clear what is meant with 'true rural African culture' as very little is offered apart from reconstructed traditional architecture, lay-out of homesteads, a few traditional objects and traditionally based 'tribal' dances. 
All these performances and objects can be questioned in terms of their authenticity and significance for heritage conservation. Van Veuren (2004: 151) mentions that these dances are performed with 'masks unlike any found in indigenous South African cultures'. In addition these dances are not representative of any particular cultural group in South Africa and thus not authentic and true in the objective sense of the word.

The food served in the restaurant can, according to Van Veuren (2004: 151), best be described as representative of a 'pan-African menu'. However, as far as the local indigenous cultural groups are concerned, this food offer can seriously be questioned in terms of its authenticity. Crocodile meat was never part of the indigenous diet while visitors have to help themselves to the food as it is offered as a buffet. Nothing of the traditional etiquette regarding the serving and eating of food is adhered to.

The village serves as a perfect example of commoditisation and even distortion of cultural objects and practices. The village will clearly not satisfy the expert - the ethnographer or anthropologist - who are inclined to take an attitude of objective detachment during these kind of presentations. Hence, the village is heavily focused on the non-local with very little (if any at all) knowledge of African cultures who 'will more easily fall prey to sophisticated forms of covertly "staged authenticity"' (Cohen1988:377).

Due to Lesedi's success it seems as if the owners have to a large extent succeeded in staging those aspects of 'traditional culture' which satisfy 'the existential, more specifically the recreational tourists as marks of authenticity, according to their own, strict criteria' (Cohen 1988:377).

In view of the inauthenticity of Lesedi Cultural Village in terms of toured objects and practices, modern day amenities and comforts, it is the conclusion that the success of Lesedi should largely be ascribed to its recreational value, enabling visitors to release feelings of spontaneity and joyful emotions that are often inhibited by a monotonous routine of everyday modern life that leads to feelings of 'existential inauthenticity' (Wang 1999:358-360). Hence, it is only from an existential, and more particularly recreational existential point of view that Lesedi, as a privately owned cultural village, does bear some authentic value. In terms of cultural heritage conservation its significance is highly questionable.

\section{Thomo Living Cultural Heritage Museum}

\section{Characteristics}

'Thomo Living Cultural Heritage Village' falls under the second type of cultural villages as it is owned by members of the local community. In actual fact the village forms part of a greater initiative, the Thomo Heritage Park Project which was 
implemented between the years 2008 and 2009 by Tinghwazi Arts, Culture and Tourism Primary Co-operative Ltd., a local community-based organisation, in association with MINTEK Ltd. The project was funded by the European Union and the National Development Agency of South Africa. The village is located on the eastern shore of the Nsami Dam in the Mopani District of the Limpopo Province of South Africa (Thomo Heritage Park Document 2010:1).

Thomo Living Cultural Heritage Museum is intended to be a replica of a Late Iron Age traditional Tsonga homestead, inhabited by a local family complete with guest huts where visitors can stay and enjoy Tsonga hospitality and culture as it was lived during the $19^{\text {th }}$ and early $20^{\text {th }}$ centuries. In addition the development also focuses on the education of school children in so far as school groups visit the cultural museum in order to create an awareness of their cultural heritage. For this purpose an 'edutainment resource centre' has also been erected close to the cultural museum to the benefit of researchers as well as the community at large. The primary motivation for its establishment was not to make a profit in the first place, but rather a strong commitment to cultural conservation, education and job creation in this sequence of priority (Thomo Heritage Park Document 2010:1).

Thomo Living Cultural Heritage Museum has, through accredited programmes, its own trained, skilled, knowledgeable and experienced guide interpreters and educators, ensuring quality interpretation and 'conveyance of multiple perspectives' and 'heritage values' to visitors (Thomo Heritage Park Document 2010:2).

\section{Evaluation}

Thomo Living Cultural Village represents a fairly honest attempt by the owners to present, in their own words, 'a true display of culture and traditions by way of traditional structures, objects, living heritage, music, dance customs, cultivation, traditional dress and indigenous cuisine'. What is of significance in this regard is the holistic approach that is followed in the presentation of culture as expressed in the Thomo Heritage Park Document (2010:1): 'Tsonga culture is like all other cultures...a complex tapestry of elements where the preparation of food for instance cannot be strictly separated from the veneration of spirits'. Furthermore, the term 'living' as it appears in the name of this cultural museum was purposely chosen as the owners acknowledge the fact of culture change and judge that it should be reflected in the presentations: 'At the risk of being trite, the Park's programs will have to be conscious of both the present and the past in order to ensure the Park's bright future' (Thomo Heritage Park Document 2010:1). Hence, a historical approach, according to Lengkeek (2008) is followed by this cultural museum

In terms of its museum-like approach this cultural museum complies to a large extent to the criteria set for objective authenticity. Not only are the toured cultural objects and practices such as works of art, rituals, cuisine, dress, museum lay-out, etc. 'made or enacted by the local people according to custom and tradition' and 
hence 'connotes...a sense of the genuine, the real or the unique' (Sharpley 1994:130, as acknowledged by Wang 1999:351), but it also provides for authentic tourist experiences. This notion of an authentic experience links with Wang's (1999: 356-360) notion of existential authenticity in the sense that it is one in which individuals feel themselves to be in touch both with a real world and with their real selves' (Handler \& Saxton 1988:243, as acknowledged by Wang 1999:351).

Although it is agreed that there is no authenticity of the original (objective authenticity) and that authenticity (reality) is rather 'the results of the versions of our interpretations and constructions' (Wang 1999:353), it is important to note that in the case of this cultural museum, it is the owners themselves as members of the local community, who interpret the toured objects and practices for the visitors. As such it leaves less room for own speculation and interpretation in terms of the real meaning of things.

However, despite a deliberate attempt to present and conserve culture, a closer look at Thomo living Heritage Cultural Village reveals some deficiencies that affects its significance in the conservation of cultural heritage. The most obvious shortcomings are the absence of a cattle kraal (with cattle) in the middle of the museum kraal, goat and chicken huts, grain storage huts as well as a sacrificial hut and an altar where sacrifices can be brought to the ancestors. In terms of the structures it appears that the sleeping huts are too big and that it is the result of the beds that were put in the huts, particular for the purposes of guest accommodation. Apparently the possible use of sleeping mats in accordance with the traditional practice was not given much consideration. In this respect the remark of Cohen (1988:378) is relevant: 'The vast majority of tourists do not demand such a "total authenticity." Even "experiential" tourists, though seriously concerned with the authenticity of their experience, and entertaining strict criteria for judgements of authenticity, will often focus in such judgements on some traits of the cultural product and disregard others'.

Hence, despite the shortcomings it is judged that this village does make a significant contribution to the conservation of Tsonga cultural heritage, not only because it does attempt to represent traditional culture but also because of its historical approach in so far as it is also committed to indicate the changes that have occurred within the context of 'living culture'.

\section{Tsonga Kraal Open-Air Museum/ Muti wa Tsonga Open-Air Museum}

\section{Characteristics}

The Tsonga Kraal Open-Air Museum falls under the third type of cultural villages and was established in the mid 1970's of the previous century as a government initiative. The Tsonga Kraal is situated in the Hans Merensky Nature Reserve next to Eiland Holiday Resort in Limpopo Province which has been its main source of 
visitors. A curator is responsible for the management of the kraal and the development of programmes.

The Tsonga Kraal Open-Air Museum represents a deliberate attempt to present the traditional culture of the Tsonga as true and comprehensive as possible.

Considerable scientific research of an archaeological and anthropological character by the University of the Witwatersrand and the Museum Service Division preceded the establishment of the Museum.

The maintenance of the Museum and presentation of Tsonga culture fall under the control of the curator who has always been a graduated person in Anthropology. In the process various facets of Tsonga culture is depicted by Tsonga experts (male and female) - from technology (architecture displaying different types of Tsonga structures sleeping huts, cooking huts, grain stores, a goat hut, a chicken hut, a cattle kraal and a sacrificial hut), material objects and the manufacturing thereof (wooden bowls and plates, clay pots, baskets, beer filters, musical instruments, the smelting and forging of iron, the production of salt), social relations within a family (the difference in relation between a kraal head and his different wives, the relation between the wives, the position of children, gender relations), economic activities (cultivation of crops, animal husbandry - keeping of cattle, goats and chickens) to religion (the altar where sacrifices are offered to the ancestors and the spirit hut in the centre of the kraal) (Tsonga Kraal Open-Air brochure). Visitors are encouraged to view and handle the household implements which are manufactured by the artisans.

The Tsonga Kraal Open-Air museum has also facilitated some festivals and events on the Tsonga cultural calendar. In the process it has attracted people from some chiefdoms among the Tsonga in the region. The festivals of the 'Opening of the planting season' (Ku dzima xikomu), and the 'Harvesting of the first fruit' (Ku luma vukanyi) serve as examples. Simultaneously indigenous knowledge, traditions and the role of women, as the real agriculturalists, are honoured and celebrated.

\section{Evaluation}

The Tsonga Kraal Open-Air Museum is an example of an honest attempt to display the traditional Tsonga culture as real and objective as possible. Although the museum was initiated from outside, it was established in accordance with the information that had been provided by local experts to the researchers. This does not imply that the museum kraal is without any deficiencies. Certainly the most important lacuna of the museum kraal is the fact that it is not a 'living kraal' in the sense that the performers also live in it. Due to various problems in the past, the local staff are accommodated in a quarter close to the museum kraal.

Due to the fact that the Tsonga do not live according to the traditional pattern anymore but have been resettled in planned rural villages and townships, the Tsonga Kraal Open-Air Museum serves as a fairly good example of 'staged authenticity'. It is clearly also a-historical (cf. Lengkeek 2008) in so far as it focuses 
on the $19^{\text {th }}$ century without any attention to cultural changes since then. Due to the fact that the primary function of the museum kraal is to conserve and to educate, the entertainment of visitors plays a secondary role. Hence, it is expected that the existential experience may be extremely limited and not complying with the expectations of these type of tourists, in particular the recreational tourist (cf. Cohen 1988:377).

\section{Tentative conclusions}

In the introduction we posed the question if cultural villages in South Africa are to be considered a proper and effective way to conserve a particular heritage. In order to be able to answer that question we juxtaposed three notions of authenticity as distinguished and conceptualised by Wang (1999) with the three types of cultural villages as distinguished by van Veuren (2004). The juxtaposition was empirically grounded in an (interrupted) 15 year fieldwork and study on cultural villages in South Africa by the first author of the article.

Lesedi Cultural village fits the first category of cultural villages, those privately owned by outsiders. Its significance as centre for the conservation of cultural heritage, has to be seriously questioned. It appears that the main purpose of this category of cultural villages is to make profit primarily by means of the entertainment of visitors. Hence there is a deliberate attempt to satisfy the expectations of visitors by means of the presentation of objects and performances which are mostly based on stereotypical images of different peoples in different parts of South Africa. In the process indigenous cultures are commoditised in the sense that cultural objects and practices are reduced and sanitised to conform to tourist expectations, losing their authentic values and meanings.

Although categorised as belonging to the second type of villages, Thomo Living Cultural Heritage Museum displays remarkable resemblances with the characteristics of the third category of cultural villages (as often happens with using typologies to categorise fieldwork cases). The most obvious resemblance in both cases is the dedication to cultural conservation and education (cf. Van Veuren 2004: 141). Both these villages have become cultural centres where training programmes are provided and important ceremonies, festivals and events on the traditional calendar are performed. Hence the centres serve not only to conserve traditional culture, but also to conduct research, to teach and to encourage participation and by doing so popularise living heritage. Hence, in both instances people are made aware of their roots and as such it promotes cultural awareness and a sense of identity in a relaxed and joyful way. It can be assumed that this approach will attract those visitors who are knowledgeable about culture and who are interested in a learning rather than an entertainment experience per se. We can tentatively conclude that Thomo Living Cultural Heritage Museum contributes significantly to a historically authentic conservation of cultural heritage. 
Tsongakraal Open-Air museum is to be distinguished from Thomo Cultural Village in three respects, the first being that it is a-historical display of cultural heritage. Secondly, Thomo Living Cultural Heritage Museum is a living village in the sense that a local family in fact lives in it and have to generate their own income while in the case of the Tsongakraal Open-Air museum, the salaried staff sleep in quarters outside but adjacent to the museum kraal. Thirdly, although Thomo Living Cultural Heritage Museum takes a historical approach to presenting the cultural heritage it nevertheless seems to miss some of the authentic object details in comparison with the Tsongakraal museum. As such, these two villages supplement each other in a certain sense. The Tsongakraal Open Air Museum also contributes to conserving a particular a-historical interpretation of cultural heritage. Our analysis can tentatively conclude that Thomo and the Tsongakraal cultural villages in terms of authenticity both seem to complementary contribute to the conservation of heritage. On a more reflective level we might add that although we subscribe the need for the conservation of cultural heritage, we are also very much aware of the critical danger of the exoticising potential of cultural villages as a tourism destination. For many tourists from Western countries, cultural villages can be an attractive option because it satisfies their 'lust' for a particular kind of 'Others' that fit their colonially based stereotyped images of them. It is therefore adamant that the educational programmes of cultural villages pay homage to this post-colonial critique and include it in their narratives to the tourists.

\section{Bionote}

Chris Boonzaaier (PhD), is an Associate Professor of Anthropology at the University of Pretoria. He is Programme Manager of a 3-year degree course in Heritage and Cultural Tourism. His research interests include community-based tourism development and cultural landscapes from a community-based perspective.

Harry Wels Harry Wels (PhD), is Associate Professor at Vrije Universiteit Amsterdam, Publication Manager at the African Studies Centre Leiden, both in the Netherlands and Extra Ordinary Professor at the University of the Western Cape, South Africa. His research interest is on human animal relations in private wildlife conservation in southern Africa.

\section{Bibliography}

Acheraïou, A. 2011 Questioning hybridity, postcolonialism and globalisation. London: Palgarve Macmillan.

Adler, P.A. \& P. Adler 1994 Observational techniques. In Denzin, N.K. \& Y.S. Lincoln (eds.) Handbook of qualitative research. London: Sage. 
Bhabha, H.K. 1983 The other question: The stereotype and colonial discourse. In: Evans, J. \& S. Hall (eds.) Visual culture. The reader. London: Sage Publications, New Delhi: Thousand Oaks, pp. 370-378.

Bhabha, H.K. 1994 The location of culture. London: Routledge.

Boonzaaier, C.C. \& Grobler, J.H.F. 2012 Community perceptions of tourism in the Tshivhase area of the Limpopo Province, South Africa. Anthropology Southern Africa 35(3\&4):60-70.

Booyens, I. 2010 Rethinking township tourism: Towards responsible tourism development in South African townships, Development Southern Africa, 27(2), 273287

Brochure: Tsonga Kraal Open-Air Museum. Unpublished.

Cohen, E. 1988 Authenticity and Commodification in Tourism. Annals of Tourism Research, 15: 371 - 386.

Coertze, R.D. 1993 Participant observation: Observational interrogation or interrogation in depth. South African Journal of Ethnology. 16(3): 69-79.

De la Harpe, R., Harpe, P.M., Leitch, B. \& S. Derwe 1999 Zulu. Cape Town: Struik. Echtner, C.M. \& Prasad, P. 2003 The content of Third World marketing. Annals of Tourism Research 30(3):660-682.

Greenwood, D.J. 1989 Culture by the pound: an anthropological perspective on tourism as cultural commoditization. In: Smith, V.L. (ed.) Hosts and Guests. $\left(2^{\text {nd }}\right.$ ed.) Philadelphia: University of Pennsylvania Press.

Hammersley, M. \& Atkinson, P. 1983 Ethnography: Principles in practice. London: Tavistock publications.

Kamberelis, G. \& Dimirtiades, G. 2013 Focus groups: From structured interviews to collective conversations. Abingdon, Oxon; New York, NY: Routledge.

Lengkeek, J. 2008 The authenticity discourse of heritage. In: Breeze, D.J. \& S. Jilek (eds.) Frontiers of the Roman empire. The European dimension of a World Heritage Site. Historic Scotland: Edinburgh. (pp. 37-53).

MacCannell, D. 1973 Staged authenticity: Arrangements of social space in tourist settings. American Journal of Sociology 79(4): 589-603.

Marschall, S. 2007 Constructing Identity through Cultural and Heritage Tourism in South Africa. In: Wishitemi, B., Spenceley, A. \& H. Wels (eds.) Culture and Community: Tourism Studies in Eastern and Southern Africa. Amsterdam: Rozenburg, pp.155-172. 
Monare, M., Moswete, N., Perkins, J. \& Saarinen, J. 2016 Emergence of Cultural Tourism in Southern Africa: Case Studies of Two Communities in Botswana. In: Manwa, H., Moswete, N. \& J. Saarinen (eds.) Cultural Tourism in Southern Africa. Bristol, Buffalo, Toronto: Channel View Publications.

Ndlovu, M. 2013 The production and consumption of cultural villages in South Africa: A decolonial epistemic perspective. Africanus 43(2): 51-63.

Palmer, C.A. 1994 Tourism and colonialism: The experience of the Bahamas. Annals of Tourism Research 21(4):792-811.

Robinson, M. 1999 Cultural Conflicts in Tourism: Inevitability and Inequality. In: Robinson, M. \& P. Boniface Tourism and Cultural Conflicts. CABI publishing. Saarinen, J. 2007 Cultural Tourism, Local Communities and representations of Authenticity: The Case of Lesedi and Swazi Cultural Villages in Southern Africa. In: Wishitemi, B., Spenceley, A. \& H. Wels (eds.) Culture and Community: Tourism Studies in Eastern and Southern Africa. Amsterdam: Rozenburg, pp.139-154.

Said, E.W. 1978 Orientalism, New York: Random House

Scheyvens, R. 2002 Tourism for development. England: Pearson Education Ltd.

Schurink, W.J. 1998 Participant observation. In De Vos, A.S. (ed.) Research at grass roots. Pretoria: J.L. van Schaik.

Sezgin, E. and Yolal, M. 2012 Golden age of mass tourism: Its history and development, in: Kasimoglu, M. (ed.), Visions for global tourism industry - Creating and sustaining competitive strategies, Rijeka: InTech. Available from: http://www.intechopen.com/books/visions-for-global-tourism-industry-creatingand-sustaining-competitive-strategies/mass-tourism-its-history-and-developmentin-the-golden-age

Spradley, J.P. 1979 The ethnographic interview. New York: Holt, Rinehart \& Winston.

Strydom, H. \& C.S.L. Delport 2005 Information collection: Participant observation. In De Vos, A.S. (ed.) Research at grass roots. $3^{\text {rd }}$ ed. Pretoria: J.L. van Schaik. Thomo Heritage Park Document 2010 Thomo Heritage Park. Giyani: Tinghwazi Arts Amalgamation.

Tomaselli, K.G. \& Wang, C. 2001 Selling myths, not culture: Authenticity and cultural tourism. Tourism Forum Southern Africa 1(1): 23-33.

Urry, J. 1990 The tourist gaze: Leisure and travel in contemporary societies. London: Sage. 
Van der Waal, K. 2009 Getting going: Organizing ethnographic fieldwork, in: Ybema, S., Yanow, D., Wels, H. and Kamsteeg, F. (eds.) Organizational ethnography: Studying the complexities of everyday life (pp. 1-20). Los Angeles, London: Sage, 2339.

Van Veuren, E.J. 2004 Cultural village tourism in South Africa: Capitalizing on indigenous culture. In: Rogerson, C.M. \& G. Visser (eds.) Tourism and development issues in contemporary South Africa. Pretoria: Africa Institute of South Africa.

Van Vuuren, C.J. 1983 Die vestigingspatroon van die Suid-Ndebele (The settlement pattern of the Southern Ndebele). Pretoria: MA-dissertation.

Waitt, G. 2000 Consuming heritage. Perceived historical authenticity. Annals of Tourism Research 27:835-862.

Wang, N. 1999 Authenticity in Tourism Experience. Annals of Tourism Research, 26(2): $349-370$.

Wels, H. 2004 About romance and reality: Popular European imagery in postcolonial tourism in southern Africa. In: Hall, C.M. and H. Tucher (eds.) Tourism and postcolonialism: Contested discourses, identities and representation. London: Routledge, pp.76-94. 